DOI 10.31558/2519-2949.2020.2.7

УДК 327.39:061.1ЄC+330.35(477)

ORCID ID: https://orcid.org/0000-0002-7739-7232

Хевцуріані А. Т., Грузинський технічний університет (Тбілісі, Грузія)

\title{
ОСНОВНІ ПОЗИТИВНІ ТА НЕГАТИВНІ РИСИ ЄВРОІНТЕГРАЦІЇ УКРАЇНИ
}

Статтю присвячено аналізові основних переваг та негативних аспектів європейської інтеграиії Украӥни. Зроблено висновок про те, щцо ідеї європейської та євроатлантичної інтеграчії України мають глибокі історичні корені. Українсько-європейські відносини завжди були досить тісними. І ие природне явище, адже Україна є частиною європейської иивілізачї як територіально, так $i$ зі своїми історико-культурними иінностями. В иеей час Украйна також є членом більше ста міжнародних організачій. Звичайно, європейський вибір відкриває нові перспективи співпраці між Україною та розвинутими країнами, економічного розвитку, соціального та інтелектуального прогресу. На сучасному етапі Украӥна є пріоритетним партнером для Європейського Союзу. Водночас ЄС допомагає Украӥні забезпечити стабільне, проивітаюче та демократичне майбутнє ї громадян іє незмінним у своїй підтримиі незалежності Украйни, ї̈ територіальної иілісності й суверенітету. Угода про асоціацію, включаючи створену в ї̈ рамках Поглиблену і всеосяжну зону вільної торгівлі (DCFTA), угода щодо якої підписана в 2014 роиі, є основним інструментом зближення Украӥни та СС, оскільки ще сприяє посиленню політичних зв 'язків, зміцненню економічних відносин і шанобливого ставлення до спільних цінностей. Україна реалізує амбітну програму реформ, спрямованих на прискорення економічного зростання та підвищення рівня життя ї̈ громадян. Для Украӥни європейська інтеграиія є засобом модернізації економіки, залучення іноземних інвестиџій та нових технологій, підвищення конкурентоспроможності вітчизняних виробників та можсливість виходу на єдиний внутрішній ринок СС. Звичайно, все вищезазначене є принципово важливим для украӥнської держави, але європейська інтеграція країни є особливо важливою з точки зору ї̈ національної безпеки, щуо є завданням номер один для сталого розвитку країни.

Ключові слова: Украӥна, Росія, геополітика, безпека, євроатлантична інтеграчія.

Ідеї європейської та євроатлантичної інтеграції України мають глибокі історичні корені. Українсько-європейські зв'язки завжди були досить тісними. I це явище є закономірним, оскільки Україна $\epsilon$ частиною європейської цивілізації як територіально, так і своїми історичними й культурними цінностями. Наразі Україна також є членом понад ста міжнародних організацій.

Безумовно, європейський вибір відкриває нові перспективи - співробітництва України з розвиненими країнами, економічного розвитку, соціального й інтелектуального прогресу. Для України європейська інтеграція - це шлях до модернізації економіки, до залучення іноземних інвестицій i нових технологій, до підвищення конкурентоспроможності вітчизняного товаровиробника, можливість виходу на єдиний внутрішній ринок ЄС. Звичайно, все наведене вище $є$ принципово важливим для Української держави, але європейська інтеграція країни особливо важлива з точки зору іiї національної безпеки, що є завданням номер один для сталого розвитку країни.

Як нам відомо, на сучасному етапі сформовано принципово інший підхід щодо феномену безпеки, який уже сформувався в наукових колах як незалежна дисципліна, що вийшла за рамки міжнародних відносин. Проблема безпеки для вільного світу є головним викликом XXI століття. Відповідно, він як головний фундамент державності не може бути гнучким і досконалим, якщо не стане всеосяжним і не буде мати єдиного, регіонального характеру. Його стратегічною функцією насамперед має стати призупинення повзучої окупації, також необхідною є превенція інших очікуваних зовнішніх небезпек та їх миттєве припинення (тероризм, диверсія, пропаганда, м'яка сила тощо). Не тільки Україна, але й всі інші прозахідні країни, які однозначно заявляють про своє бажання інтегруватися в євроатлантичний простір, повинні максимально розширити діапазон 
безпеки і не обмежуватися лише військовою сферою. Вона додатково має охоплювати політичний, економічний, соціологічний та екологічні сектори.

Безумовно, основною перешкодою для вступу України до Свропейського Союзу та інших західних структур залишається російська окупація.

У міжнародних відносинах часто зустрічається думка, що сильний гегемон може виступати в якості стабілізуючої сили та забезпечити основні умови для процвітання політичних і економічних взаємовідносин серед своїх «підданих». Згідно з цією точкою зору, що є відомою як теорія керованої стабільності, домінантна держава (гегемон) завдяки «перевазі влади» встановлює порядок, чим забезпечує міжнародну стабільність. Дрібні держави не можуть довго існувати самостійно в конфліктному середовищі міжнародної політичної системи i стикаються 3 необхідністю об'єднатися з домінуючою державою, яка зможе забезпечити безпеку і стабільність.

На думку багатьох теоретиків, на підставі цієї теорії сучасна російська політична еліта намагається завоювати панування на пострадянському просторі. Його мета - нав'язати цивілізованому світу міф про те, що пострадянські республіки є цілком уразливими щодо свого суверенітету, що їх роль і функції в регіоні незначні. Відповідно, вони хочуть представити себе в якості певної гарантії стабілізації на всьому пострадянському просторі. На жаль, завдяки своїй потужній пропаганді, а також за допомогою клептократії, вони в деяких випадках здатні переконати деякі західні кола, включаючи й декілька західних лідерів.

Насправді все простіше. Росія як головна загроза суверенітету пострадянських країн до сьогоднішнього дня не може повноцінно вийти з геополітичного шоку, викликаного розпадом Радянського Союзу. Це проявляється, насамперед, в їі відносинах з колишніми союзними республіками. Для звільнення від комплексів минулого й для переходу на новий етап взаємовідносин, колишнім метрополіям (відносно колишніх колоній) зазвичай необхідний певний період, хоча у випадку з Росією цей час триває незвично довго. Зазначене змушує серйозно думати, що Росія просто не бажає розвивати нормальні, рівноправні відносини 3 пострадянськими республіками.

Після подій 2014 р. в Україні стало ясно, що Москва збирається провадити більш жорстку зовнішню політику, ніж це було до кризи. Вона заявляє претензію на придбання особливого геополітичного впливу біля іiі кордонів із застосуванням різноманітних методів, намагається реалізувати процес так званої євразійської інтеграції. Для досягнення цієї мети вона не соромиться проводити прямі й гібридні військові кампанії, як це було по відношенню до Грузії й України. В інших випадках Росія здійснює це за допомогою своєї потужної пропаганди та з використанням економічних важелів.

Виникає питання: а чому саме Україна? Відомий американський стратег і політолог Збігнєв Бжезинський вважав Україну головною перешкодою імперіалізму Росії, і не дарма [1]. Повалення суверенітету України стало головною метою Росії з моменту його отримання. Але чому ії так дратує український суверенітет і державність? Звичайно, справа не лише в її територіях і масштабах, тут також дуже важливо враховувати й ідеологічний чинник. Україна як успішна і розвинута європейська держава $є$ прямим смертним вироком як євразійській філософській течії А. Дугіна, так і концепції суверенної демократії В. Суркова. Урешті-решт, все це рівноважно краху нинішньої системи, створеної В. Путіним.

Все почалося після того, як у 2013 році тодішній український уряд вирішив призупинити процес підписання Угоди про асоціацію з Свросоюзом. Це рішення призвело до масової акції протесту в центрі Києва, а також в інших містах України, яка отримала в соціальних мережах і ЗМІ назву «Євромайдан», за аналогією з подіями 2004 року. Сотні тисяч громадян України вийшли на вулицю й вимагали від влади скасувати таке рішення, у відповідь уряд відповів насильницьким розгоном мітингу, в результаті якого загинули сотні протестувальників. Отже, воля і сила народу виявилися сильнішими від влади узурпатора Януковича, що призвело до його повалення і втечі 3 країни.

Україна знову перемогла і захистила своє європейське майбутнє, але все це обійшлося ій дуже дорого: сусід-агресор спочатку анексував Крим, а потім інспірував справжню війну в східному регіоні країни.

Звичайно, на цьому складному історичному шляху було чимало розчарувань, які, ймовірно, продовжаться в майбутньому. Інфантильне ставлення деяких європейських країн та їх невичерпні економічні інтереси, безумовно, підривають інтереси України, яка бореться проти агресора. Сьогодні, безперечно, можна вважати, що територія України (і не тільки) уявляє собою своєрідне геополітичне депо, де розташовані ешелони російської агресії. $€$ сумнів, що наявний статус-кво 
не надто дратує деяких західних лідерів. Для них головне, щоб ці ешелони не взяли курс на захід. Виходить, що Україна й ті пострадянські країни, які також піддалися агресії 3 боку Росії, представляють просто буферну зону на стику інтересів двох найбільших геополітичних гравців. Вони повинні зрозуміти, що така геополітична обстановка не в наших національних інтересах. Безумовно, Україна потребує більшої підтримки й допомоги в цій боротьбі - як моральної, так $і$ фінансової, матеріальної. Водночас потребується набагато сильніший тиск на агресора. Саме в цьому напрямку має бути більше роботи з партнерами.

На Південному Кавказі, особливо в Грузії, уважно стежать за розвитком подій в Україні. Це зовсім не дивно, тому що крім тісного історичного зв'язку ці країни і на сучасному етапі об'єднують ідентичні геополітичні виклики та проблеми. У Грузії не лише переживають за Україну, але й 3 надією дивляться в майбутнє дружньої країни. Україна, як одна 3 найбільших держав Європи, враховуючи свій гіркий історичний досвід, після відновлення державної незалежності зробила геополітичний вибір, що однозначно відбилося у прагненні інтегруватися в західні структури. Україна з самого початку активно співпрацювала з численними міжнародними організаціями, а також з провідними західними країнами. Саме з цим періодом пов'язана та дивовижна історична помилка, якої припустився український уряд у 1994 році, - мова йде про т. зв. «Будапештський меморандум», згідно з яким Україна в обмін на недоторканність суверенітету і територіальну цілісність передала, як виявилося, майбутньому агресору, третій за величиною в світі арсенал ядерної зброї. Україну було обмануто, більше того - зраджено, тому що в 2014 році, коли один із гарантів цього меморандуму - Російська федерація, скориставшись напруженою ситуацією, яка склалася на той час в Україні, окупувала частину їі території, інші гаранти (США і Великобританія) навіть не поворухнули пальцем, щоб захистити іiі. Звичайно, незалежно від того, скільки часу пройде, для США та Великобританії (вже не кажучи про Росію) цей випадок обов'язково залишиться чорною плямою. Виходячи з цього, Україна є єдиною державою у світі, яка має повне моральне й юридичне право відновити свій ядерний статус і стати наддержавою. Звичайно, це $\epsilon$ далекою перспективою, але зовсім не ілюзійною, перед цим вона повинна чітко визначити свої регіональні амбіції та заявити про них. Україна одночасно належить центральній, східній і південній Європі. Така геополітична розкладка, плюс територіальний, людський фактор природних ресурсів, $\epsilon$ найважливішими передумовами з точки зору їх формування регіональним полюсом. А подібна конфігурація перетворить Україну на новий центр тяжіння для пострадянських держав, що буде великим ударом по російській неоімперіалістичній та реваншистській політиці. Звичайно, Грузія як друг і стратегічний партнер України завжди вітає розвиток такого сценарію.

Як ми знаємо, першого вересня 2019 р. набула чинності Угода про вільну торгівлю між Україною та ЄС. Водночас Україна заявила, що ії стратегічним національним пріоритетом $є$ подання заявки на членство в СС до 2020 року. Звичайно, на сьогоднішній день це не реально - не лише через проблеми, пов'язані з поширенням коронавірусу, але й тому, що держави-члени СС не мають єдиної думки щодо цього питання, розширення Євросоюзу сприймається ними як складний виклик для еліт і громадян $\mathrm{CC.}$

Цікаву думку щодо вищенаведеного питання висловив відомий шведський економіст, старший науковий співробітник «Atlantic Council» Андерс Аслунд. За його словами, на нинішньому етапі Україна та ще п'ять потенційних кандидатів у СС із Південно-Східної Європи перебувають у схожій ситуації. Їм доводиться чекати своєї черги, реалізуючи реформи та переконуючи ЄС у перевагах розширеного членства. Чи будуть ці кандидати зрештою прийняті в $Є \mathrm{C}$ - залежить від успішності їх реформ і благополуччя в цих державах. Якщо вони будуть спільно провадити реформи та демонструвати прогрес - то прискорять приєднання до СС всіх кандидатів. Це довів приклад скандинавських країн, країн Балтії, Бенілюксу та «Вишеградської четвірки» [2].

Звичайно, думка експерта в жодному разі не $\epsilon$ необгрунтованою, членство в $Є С$ дійсно $\epsilon$ складним процесом і пов'язано з багатьма перешкодами, про що свідчить і його історичний досвід. Але в зв'язку з цим Аслунд має і свої рекомендації: він вважає, що Україні краще подати заявку на членство в Центрально-Свропейській асоціації вільної торгівлі (CEFTA) [2].

Штаб-квартира Центрально-Свропейської асоціації вільної торгівлі знаходиться в Брюсселі. Цю організацію в 1992 році заснували Польща, Чехословаччина й Угорщина - країни «Вишеградської четвірки». I, слід визнати, CEFTА виявилася дуже корисною для підготовки країн до членства в СС. Членство в CEFTA вимагає, щоб кандидати були членами Всесвітньої торгової організації (СОТ), мали Угоду про асоціацію з СС, а також угоди про вільну торгівлю з нинішніми членами CEFTA. В принципі, все це полегшує торгівлю й готує держави до вступу в СС. 
Ми можемо частково погодитися з думкою Андерса Аслунда. Членство в СЕФТА, безумовно, $\epsilon$ одним із способів вступу до ЄС, і такий прецедент дійсно мав місце. Але у випадку з Україною ми маємо справу із зовсім іншою ситуацією, оскільки Україна перебуває в зовсім іншій реальності, ніж країни, які в той час сформували або стали членами цієї організації. Україна перебуває у стані війни, частину іiі території окуповано, тому вона потребує прискореної інтеграції в євроатлантичні структури. Європа повинна раз і назавжди усвідомити, що сильна та єдина Україна насамперед в їі інтересах.

На сьогоднішній день Україна є пріоритетним партнером для Європейського Союзу. ЄС допомагає Україні забезпечити стабільне, процвітаюче та демократичне майбутнє ії громадян і $\epsilon$ незмінним у своїй підтримці незалежності України, іiї територіальної цілісності й суверенітету. Угода про асоціацію, включаючи створену в її рамках Поглиблену і всеосяжну зону вільної торгівлі (DCFTA), угода щодо якої підписана в 2014 році, є основним інструментом зближення України та ЄC, оскільки сприяє посиленню політичних зв'язків, зміцненню економічних відносин і шанобливого ставлення до спільних цінностей. Україна реалізує амбітну програму реформ, спрямованих на прискорення економічного зростання та підвищення рівня життя ії громадян. До першочергових реформ належить боротьба з корупцією, реформа судових органів, конституційна та виборча реформи, поліпшення ділового клімату й зростання енергоефективності, а також реформа державного управління й децентралізація. 32014 року ЄС і європейські фінансові інститути виділили пакет допомоги в розмірі понад 15 млрд євро у вигляді грантів і кредитів на підтримку процесу реформ, але за суворої умови подальшого прогресу [3].

Отже, шлях до європейської інтеграції є більш корисним та привабливим для України. Водночас поточна політична дійсність, пов'язана як із зовнішніми, так і з внутрішньополітичними чинниками, значно уповільнює рух України у цей бік. Ідеї європейської та євроатлантичної інтеграції України мають глибокі історичні корені. Українсько-європейські відносини завжди були досить тісними. I це природне явище, адже Україна є частиною європейської цивілізації як територіально, так і зі своїми історико-культурними цінностями. В цей час Україна також $\epsilon$ членом більше ста міжнародних організацій. Звичайно, європейський вибір відкриває нові перспективи співпраці між Україною та розвинутими країнами, економічного розвитку, соціального та інтелектуального прогресу. Для України європейська інтеграція означає одночасно і спосіб модернізації економіки, і засіб залучення іноземних інвестицій та нових технологій, важіль підвищення конкурентоспроможності вітчизняних виробників та можливість виходу на єдиний внутрішній ринок ЄС. Звичайно, все вищезазначене $є$ принципово важливим для української держави, але європейська інтеграція країни $є$ особливо важливою 3 точки зору іiі національної безпеки, що є завданням номер один для сталого розвитку країни.

\section{Бібліографічний список:}

1. Бжезинский Зб. Великая шахматная доска (Господство Америки и ее геостратегические императивы) / пер. О. Ю. Уральской. М.: Международные отношения, 1998. 256 с.

2. Аслунд А. Европейская интеграция. Что нужно Украине. URL: https://nv.ua/opinion/evropejskajaintegratsija-chto-nuzhno-ukraine-1960837.html

3. EU Neighbours south-east. URL: https://www.euneighbours.eu/ru/vostok/stay-informed/publications/ otnosheniya-es-ukraina-v-faktakh-i-cifrakh

4. Украина-EC: проблемы интеграции. URL: http://gazeta.zn.ua/international/ukraina-es-problemy-integracii-_html

5. Вопрос европейской интеграции - приоритет внешней политики Украины.

URL: http://partyofregions.ua/news

\section{References:}

1. Bzhezinskiy Zb. Velikaya shahmatnaya doska (Gospodstvo Ameriki i ee geostrategicheskie imperativyi) / per. O. Yu. Uralskoy. M.: Mezhdunarodnyie otnosheniya, 1998. $256 \mathrm{s.}$

2. Aslund A. Evropeyskaya integratsiya. Chto nuzhno Ukraine. URL: https://nv.ua/opinion/evropejskajaintegratsija-chto-nuzhno-ukraine-1960837.html

3. EU Neighbours south-east. URL: https://www.euneighbours.eu/ru/vostok/stay-informed/publications/ otnosheniya-es-ukraina-v-faktakh-i-cifrakh

4. Ukraina-ES: problemyi integratsii. URL: http://gazeta.zn.ua/international/ukraina-es-problemy-integracii-_html

5. Vopros evropeyskoy integratsii - prioritet vneshney politiki Ukrainyi. URL: http://partyofregions.ua/news

Khevtsuriani A. T. Main positive and negative features of Ukraine's European integration

The paper is devoted to the analysis of the main advantages and negative aspects of Ukraine's European integration. It is concluded that the ideas of European and Euro-Atlantic integration of Ukraine 
has deep historical roots. Ukrainian - European relations have always been quite tight. And this is a natural phenomenon, because Ukraine is part of European civilization both territorially and with its historical and cultural values. At this time, Ukraine is also a member of more than one hundred international organizations. Of course, the European choice opens up new prospects for cooperation between Ukraine and developed countries, economic development, social and intellectual progress. Today, Ukraine is a priority partner for the European Union. The EU helps Ukraine to ensure a stable, prosperous and democratic future for its citizens and is unchanging in its support for Ukraine's independence, territorial integrity and sovereignty. The Association Agreement, including the Deep and Comprehensive Free Trade Area (DCFTA), signed in 2014, is a key instrument for rapprochement between Ukraine and the $E U$, as it strengthens political ties, strengthens economic relations and respects common values. Ukraine is implementing an ambitious program of reforms aimed at accelerating economic growth and raising the living standards of its citizens. For Ukraine, European integration is a way of modernizing the economy, attracting foreign investment and new technologies, increasing the competitiveness of domestic producers, and the opportunity to enter the single EU internal market. Of course, all of the above is fundamentally important for the Ukrainian state, but the European integration of the country is especially important in terms of its national security, which is the number one task for the country's sustainable development.

Key words: Ukraine, Russia, geopolitics, security, Euro-Atlantic integration. 